\title{
COVID-19 AND THE DIGITAL TRANSFORMATION OF EDUCATION: THE CASE OF LATVIA AND LITHUANIA
}

\author{
Sandra Trinkūnienè \\ Kaunas University of Technology, Lithuania \\ Loreta Juškaite \\ Riga Technical University, Latvia
}

\begin{abstract}
Educational ecosystem is facing rapid changes due emerging technologies and their rapid penetration to daily use. When the COVID-19 pandemic emerged, it only accelerated many of these trends. Nevertheless, some education systems have been able to adapt to the changing situation and digital transformation more easily than others. Digital competence is essential for learning, work and active participation in society in digital transformation context. Given the pressure of change on existing learning institutions and learning models, ICT offers broad opportunities for developing a different view. In order for digital education actors to adapt to the digital transformation in the education sector, they also need to have the skills needed to use technology effectively. However, there is a lack of computer and technological literacy. In Latvia and Lithuania, about one in three workers has limited or no digital skills, and most STEM vacancies remain unfilled because workers do not have the necessary competencies and are not inclined to study or retrain. The aim of the study is to assess the effect of dynamic capabilities for added value educational outcomes during COVID-19 recession. The results of the study revealed that dynamic capabilities have a direct positive effect on value based education outcomes.
\end{abstract}

Keywords: digital transformation, dynamic capabilities, education, e-learning, lifelong learning.

\section{Introduction}

Digital transformation is defined as „the process through which companies converge multiple new digital technologies, enhanced with ubiquitous connectivity, with the intention of reaching superior performance and sustained competitive advantage, by transforming multiple business dimensions <...>" (Abdelaal, Khater, \& Zakil, 2018, p. 7). Digital transformation is different from traditional forms of strategic changes because digital technologies determined the speed of change processes and this creates an environment that is much more unstable, uncertain and complex (Matt et al., 2015; Schoemaker et al., 2018; Loonam et al., 2018). This includes changes of key education services delivery and affects procedures, as well as organizational structures and management 
Trinkūnienè \& Juškaite, 2021. Covid-19 and the Digital Transformation of Education: the Case of Latvia and Lithuania

principles in order to carry out these dynamic transitions across the organization and throughout the educational ecosystem (Matt et al., 2015). The development of information technology creates new challenges for the state, for schools as well as for society. Therefore, it is necessary to develop new abilities that could be used to diversify teaching methods to help educators and learners to orientate themselves in the modern learning process. The outbreak of the new coronavirus (COVID-19) caused unexpected and fundamental challenges in various areas of public life. In response to the threats posed by the pandemic, there is a need for rapid solutions and rapid response measures. Information gets older before we acquire the opportunity to use it because of technical innovation and insightful culture. For this reason, additional and/or expanded skills and abilities should be acquired to be flexible and adapt technological changes.

This study revolves around the question what is the relation between dynamic capabilities and value based education outcomes in rapidly changing environment.

The aim of this paper is to assess the effect of dynamic capabilities for added value educational outcomes during COVID-19 recession. Quantitative research method was applied in order to get deeper understanding about existing situation in Lithuania and Latvia.

This paper contributes to education and education innovation management literature by applying the dynamic capabilities framework to identify specific aspects of value creation and exchange. On the practical side, this paper sheds light on the current education situation in Lithuania and Latvia and helps to improve understanding of added value perceived by digitalization in education and how dynamic capabilities can help to adopt these changes.

\section{Digital Transformation in Lifelong Learning Education during COVID-19 Recession}

"The digital transformation calls for policies that foster strong foundation skills, promote life-long learning and strengthen the link between education, training and the world of work. Complementary structural policies that promote efficient resource allocation or that enhance investment in intangible assets can strengthen the link between skills and productivity. While education and training policies fall mostly under the responsibility of Member States, the EU can support human capital development by promoting cooperation and the exchange of best practices among Member States, and through targeted financial support" (ec.europa.eu, 2020). There is a growing consensus on the competencies needed according to changing environment. A wide variety of key competency formulations is shown in the Table 1, and this was already highlighted by UNESCO in 2017 (UNESCO, 2017). 
Proceedings of the International Scientific Conference. Volume V, May $28^{\text {th }}-29^{\text {th }}, 2021.221-231$

Table 1 Key Competencies (modified by the authors based on UNESCO, 2017)

\begin{tabular}{|c|c|}
\hline Basic skills & Modern skills and competences \\
\hline Learning to learn & $\begin{array}{c}\text { Collect, analyse, organize, and critically evaluate } \\
\text { information }\end{array}$ \\
\hline Personal skills & Taking responsibility for yourself and your actions \\
\hline Social skills & $\begin{array}{l}\text { Demonstrate an understanding of the world as a set } \\
\text { of connected systems }\end{array}$ \\
\hline Cognitive skills & Make effective use of science and technology \\
\hline Communication skills & Communicate effectively \\
\hline $\begin{array}{l}\text { Information and communication } \\
\text { technology }\end{array}$ & Ability to use digital tools \\
\hline
\end{tabular}

Any predictions we make now about education are bound to be partially wrong. We cannot depend on current predictions based on recent trends to carve our future educational goals, standards, and curricula in stone. Rather, we must create flexible guidelines that help prepare our students and educators to be versatile enough to succeed no matter how our unpredictable world changes around us. A succinct representation of versatility can be visualized via IBM's Tshaped individual—one who is capable of both depth and breadth (Spohrer, 2004), (see figure 1).

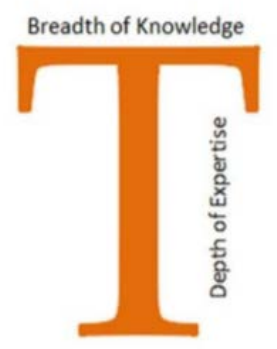

Figure1 T-Shaped Individual ( Spohrer, 2004, IBM)

An important point to underscore COVID-19 accelerating progress of invention and technology, but we can carefully manage how they are used in our lives. We need to be clear about what we want most from technologies in order to continue to reduce their negative effects and further increase their positive potential. We need to be very aware of using technology as an enabling tool to achieve our goals, not just because of its attractiveness as an innovation. Our education systems need to concentrate on universally constructive outcomes - the growth of personal abilities, skills and understanding for all learners. Both students and educators need to learn to understand the larger effects of their actions, to behave actively in the world, and to reflect and adjust as the world changes. 
Trinkūnienè \& Juškaite, 2021. Covid-19 and the Digital Transformation of Education: the Case of Latvia and Lithuania

\section{Pros and Cons of E-learning}

"As technology progresses, the education necessary to utilize it effectively also grows and education must adapt to keep up. In this way, technology and education are in a race" (C. D. Goldin and L. F Katz, 2009). "Educational institutions have recognized e-Learning as having the prospect to transform people, knowledge, skills, and performance” (Henry, 2001). Just as there are different types of e- Learning, there are also different ways of employing the technique in education. The adoption of e-learning in education process has several benefits, and given its several advantages and benefits, e-learning is considered among the best methods of education (OECD, 2020). Several studies and authors have provided benefits and advantages derived from the adoption of e-learning technologies into education process. Some studies give advantage of e-learning as its ability to focus on the needs of individual learners (Kapenieks, Daugule, 2019). E-learning strategies for delivering knowledge in digital age one of the advantages of e-learning in education is its focus on the needs of individual learners as an important factor in the process of education (rather than on the educators’ or educational institutions' needs) (Lee, Cheung, \& Chen, 2005). Each component plays an important role in an E-learning system.

Table 2 Advantages and Disadvantages of E-learning System (modified by the authors based on OECD, 2019, Henry, 2001, Kapenieks, Daugule, 2019)

\begin{tabular}{|c|c|}
\hline $\begin{array}{l}\text { Advantages of } \\
\text { e-learning to the } \\
\text { educators and/or } \\
\text { educational institutions }\end{array}$ & $\begin{array}{l}\text { - Reduced overall cost. } \\
\text { - Learning times reduced. } \\
\text { - Confidence that refresher or quick reference contents are available } \\
\text { reduces burden of responsibility of mastery. } \\
\text { - Proof of completion and certification, essential elements. of } \\
\text { training initiatives, can be automated (EU, 2019). }\end{array}$ \\
\hline $\begin{array}{l}\text { Disadvantages of } \\
\text { e-learning to the } \\
\text { educators and/or } \\
\text { educational institutions }\end{array}$ & $\begin{array}{l}\text { - Consistent delivery of content is possible with asynchronous, self- } \\
\text { paced e-learning (EU, 2019). } \\
\text { - Flexibility of education. } \\
\text { - The impersonality. }\end{array}$ \\
\hline $\begin{array}{l}\text { Advantages of } \\
\text { e-learning to the } \\
\text { students }\end{array}$ & $\begin{array}{l}\text { - Students to complete training conveniently at from home and at } \\
\text { any time. } \\
\text { - Self-directed learning for slow or quick students reduces stress and } \\
\text { increases satisfaction. } \\
\text { - Interactivity: through the e- learning system educators can directly } \\
\text { interact with student and solve their problems. } \\
\text { - Expert knowledge also available to all student and student can } \\
\text { access any time. }\end{array}$ \\
\hline $\begin{array}{l}\text { Disadvantages } \\
\text { of e-learning to the } \\
\text { students }\end{array}$ & $\begin{array}{l}\text { - Reducing cultural and social disparities. Reduced social and } \\
\text { cultural interaction can be a drawback. } \\
\text { - The impersonality. }\end{array}$ \\
\hline
\end{tabular}




\section{Dynamic Capabilities as a Driver for Added Value Education Outcomes}

Research on dynamic capabilities has seen an increasing development but been considerably limited to conceptual theories. For example, dynamic capabilities are primarily represented through a microfoundation perspective (See Figure 2). This is a view that consists of (1) sensing opportunities and threats, (2) seizing opportunities, and (3) transforming the organization's business model (Teece et al., 2007; Arndt and Pierce, 2018; Salvato and Vassolo, 2018) Researchers in the field of strategic management are primarily concerned with dynamic capability variables of integration, building, reconfiguration, modification, activation and redirecting of substantial resources and routines to gain competitive advantage. Adopting the approach of Teece et al. (1997), this study defines dynamic capabilities as the capabilities to integrate, learn and reconfigure internal and external resources and competencies in response to changing environments.

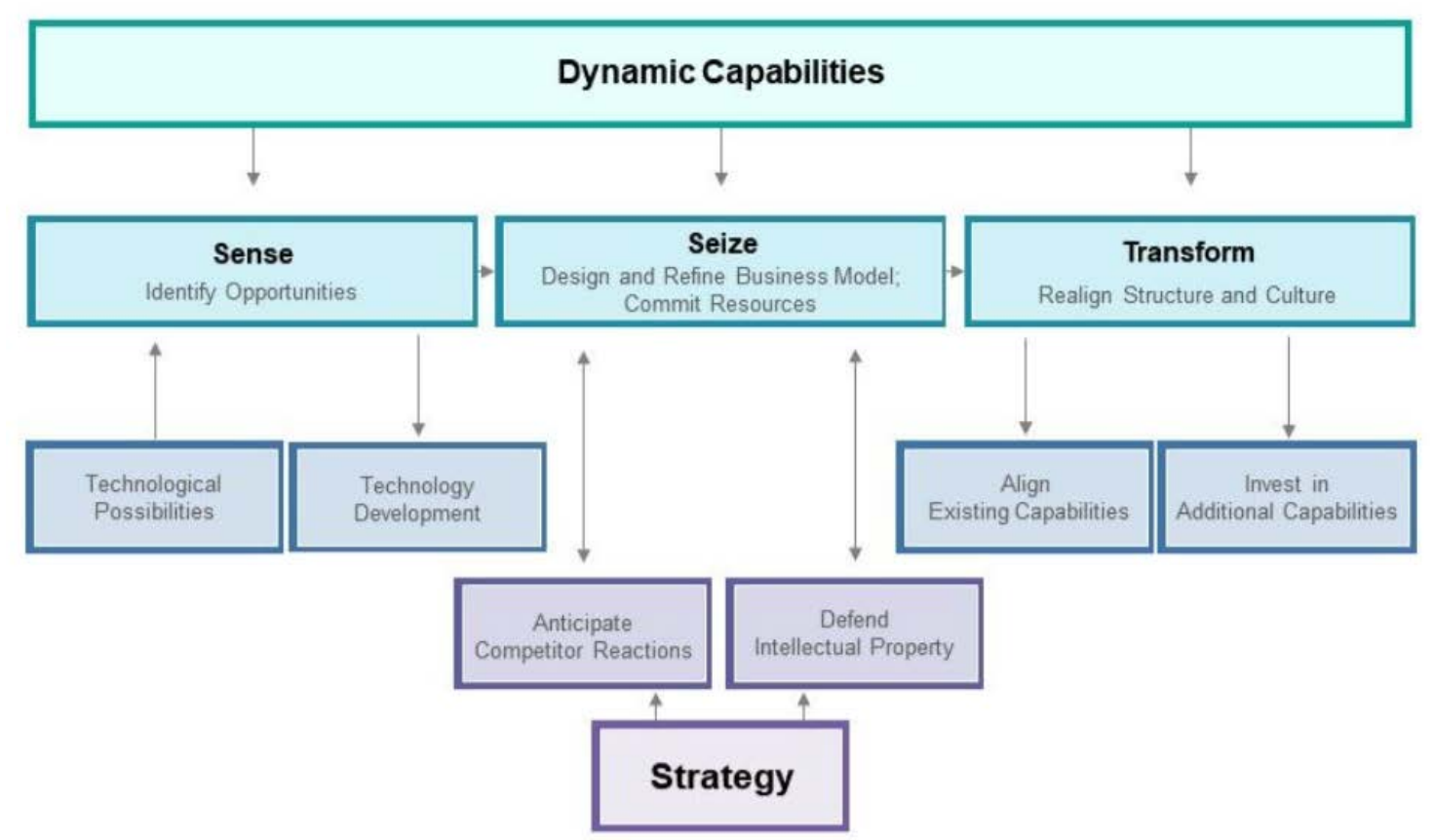

Figure2 The Key Elements of Dynamic Capabilities (modified by the authors based on Teece et al., 2007; Arndt and Pierce, 2018; Salvato and Vassolo, 2018)

Dynamic capabilities as a term itself refer to two key sub-concepts: "dynamic" and "capabilities". According to Teece et al., (1997), "dynamic is the capability to renew capabilities so that they keep pace with the changing operational environment” (p. 515). The key definitions of dynamic capabilities are provided in Table 2 . Since the digital education providers in this study operate in an a rapidly changing environment caused by COVID-19, they need to identify, 
Trinkūnienè \& Juškaite, 2021. Covid-19 and the Digital Transformation of Education: the Case of Latvia and Lithuania

develop, protect, and deploy resources and capabilities in a manner that will bestow them with a sustainable competitive advantage (Amit \& Schoemaker, 1993, p.35) and ensure value added outcomes.

Table 3 Key Definitions of Dynamic Capabilities (modified by the authors based on Zollo, and Winter (2002); Heftal et al. 2007; Teece 2007)

\begin{tabular}{|l|l|}
\hline Author & Definition \\
\hline $\begin{array}{l}\text { Zollo, and Winter, } \\
\text { (2002, p. 340) }\end{array}$ & $\begin{array}{l}\text { "A dynamic capability is a learned and stable pattern of collective } \\
\text { activity through which the organization systematically generates and } \\
\text { modifies its operating routines in pursuit of improved effectiveness". }\end{array}$ \\
\hline $\begin{array}{l}\text { Helfat et al., (2007, } \\
\text { p. 1) }\end{array}$ & $\begin{array}{l}\text { Dynamic capabilities are "the capacity of an organization to } \\
\text { purposefully create, extend or modify its resource base”. }\end{array}$ \\
\hline Teece, (2007, p.218) & $\begin{array}{l}\text { Dynamic capabilities "can be disaggregated into the capacity (1) to } \\
\text { sense and shape opportunities and threats, (2) to seize opportunities } \\
\text { and (3) to maintain competitiveness through enhancing, combining, } \\
\text { protecting and, when necessary, reconfiguring the business } \\
\text { enterprise's intangible and tangible assets". }\end{array}$ \\
\hline
\end{tabular}

According to Amit and Schoemaker (1993), dynamic capabilities are very cardinal in the efforts to gain a competitive advantage in dynamic environments (See Figure 3).

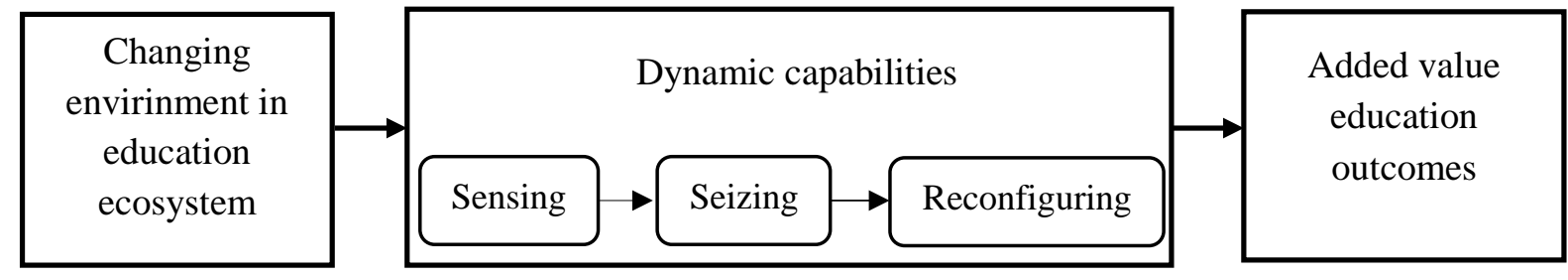

Figure3 The Impact of Dynamic Capabilities for Added Value Education Outcomes (authors)

In the educational sector, the results are called learning or education outcomes, and they are defined as "statements of what a learner knows, understands and is able to do on completion of a learning process, which are defined in terms of knowledge, skills and competence" (Mason et al., 2014, p. 74). Such added value education outcomes can only be necessitated by the dynamic capability which enables it to leverage current resources effectively, create new resources, acquire additional external resources, and eventually release existing resources to adapt to the changing environments (Lin and Wu, 2014). 


\section{Materials and Methods}

Theoretical. To assess the challenges and opportunities of digital transformation in education, desk research was carried out, assessing existing education system review and delivery of educational services during COVID-19 and comparing these results in two countries: Latvia and Lithuania. These countries were chosen for the study owing to the similarity of their education systems. Pedagogical and managerial literature, legal and educational documents were analysed.

Empirical. Besides desk research quantitative research method chosen is the survey, implemented through a self-administered questionnaire. The variables were measured using Likert-type scales, so the respondents were asked to indicate their level of agreement with the items, in a range from 1 (strongly disagree) to 7 (strongly agree). This method has been adapted in order to evaluate selfassessment (Petrulyte, 1995), the Rosenberg self- evaluation scale (SES)) and learning motivation (Entwistle, 1980, 1983), and investigate the significance of dynamic capabilities for value based educational outcomes. We prepared a questionnaire consisting of 3 sections.

The first section of questionnaire (Q1-Q5) was focused on respondents' selfassessment, learning motivation, drivers and barriers to digitalize.

The second part (Q6-16) covered the background of development the dynamic capabilities. In this section the questions were related, firstly, with the experience with digital education tools and methods. It was expected to find out what kind of digital education solution they are dealing with. The subsequent questions were address for the understanding the development of dynamic capabilities in organization and was created based on Teece (2007) dynamic capability model, where sensing (or detecting the need - info channels), seizing (or decision making) and reconfiguring (deploying or appraisal) were analysed.

The third part of the questionnaire(Q16-Q20) focused on the value based education outcomes for education ecosystem actors and this section of the questionnaire enabled us to recognize added value outputs.

Statistics. Data grouping of the research, summarize and compare, graphical data representation by Windows Microsoft Office Excel 2016 and SPSS v17 programs.

\section{Research Results}

The data collection process took place from 2nd of April 2020 to 8th of November 2020. The survey was anonymous. The questionnaire was posted in https://docs.google.com/forms by automatic mode. This study uses the key informant method to collect survey data in the private and public educational 
Trinkūnienè \& Juškaite, 2021. Covid-19 and the Digital Transformation of Education: the Case of Latvia and Lithuania

services industry in Latvia and Lithuania. In organizing the study, it was expected that despite this similarity, adaptation and adaptation will vary across countries. Analysing the answers received during the research, there was no significant difference between the respondents from Lithuania and Latvia, only slight differences in individual questions. For this reason, the data was analysed without disaggregating the results by country. Data related to the respondent $(N-278)$ is detailed in Figure 4 and Figure 5.

\begin{tabular}{llll}
\hline Position occupied & Frequency (\%) & Type of School & Frequency (\%) \\
\hline Principal & $162(58.3 \%)$ & Private & $220(79.1 \%)$ \\
Vice-principal & $8(2.9 \%)$ & Public & $32(11.5 \%)$ \\
Head of Studies & $24(8.6 \%)$ & Subsidized & $13(9.4 \%)$ \\
Department Head & $40(14.4 \%)$ & Number of students & \\
Coordinator & $10(3.6 \%)$ & Less than or equal to 100 & $132(47.4 \%)$ \\
Teacher with no extra & $28(10.1 \%)$ & Between 101 and 200 & $140(25.2 \%)$ \\
responsibilities & $2(0.7 \%)$ & Between 201 and 300 & $34(12.2 \%)$ \\
Others & $4(1.4 \%)$ & Between 301 and 400 & $14(5.0 \%)$ \\
No answer & & Between 401 and 500 & $8(2.9 \%)$ \\
Experience & $56(20.1 \%)$ & More than 500 & $18(6.5 \%)$ \\
More than 5 years & $58(20.9 \%)$ & No answer & $2(0.7 \%)$ \\
Between 5 and 10 years & & Number of educators & \\
More than 10 years & $(57.6 \%)$ & & \\
No answer & $(1.4 \%)$ & Less than or equal to 10 & $148(53.2 \%)$ \\
& & Between 11 and 20 & $74(26.6 \%)$ \\
& & Between 21 and 30 & $30(10.8 \%)$ \\
& & Between 31 and 40 & $8(2.9 \%)$ \\
& & Between 41 and 50 & $8(2.9 \%)$ \\
& & More than 50 & $8(2.9 \%)$ \\
& & No answer & $2(0.7 \%)$
\end{tabular}

Figure 4 Data Related to the Respondent $(N=278)$

Before COVID-19 pandemic the educational sector was an environment that is not subject to turbulent changes, and all changes was caused by continuous technological development. However, the COVID-19 and changed way of service delivery resulted a greater attention to the development of dynamic capabilities in order to improve learning outcomes. 
SOCIETY. INTEGRATION. EDUCATION

Proceedings of the International Scientific Conference. Volume V, May $28^{\text {th }}-29^{\text {th }}, 2021.221-231$

Statistical summary of the constructs means, standard deviations, and correlations $(\mathrm{N}=278)$.

\begin{tabular}{|c|c|c|c|c|c|c|}
\hline & Mean & $\begin{array}{l}\text { Standard } \\
\text { deviation }\end{array}$ & (1) & (2) & (3) & (4) \\
\hline $\begin{array}{l}\text { (1) Continuous } \\
\text { technological } \\
\text { development }\end{array}$ & 4.3082 & 1.05350 & $(0.901)$ & & & \\
\hline (2) COVID-19 & 3.9347 & 1.11311 & $0.686^{\mathrm{a}}$ & $(0.876)$ & & \\
\hline $\begin{array}{l}\text { (3) Dynamic } \\
\text { Capability }\end{array}$ & 4.6602 & 1.26761 & $0.572^{\mathrm{a}}$ & $0.651^{\mathrm{a}}$ & & (0.911) \\
\hline $\begin{array}{l}\text { (4) Learning } \\
\text { Outcomes }\end{array}$ & 5.0221 & 0.98657 & $0.551^{\mathrm{a}}$ & $0.550^{\mathrm{a}}$ & & $0.662^{\mathrm{a}}(0.922)$ \\
\hline
\end{tabular}

The square root of the average variance extracted (AVE) is reflected on the diagonal of the matrix.

a The correlation is significant at the level of 0.01 (bilateral).

Figure 5 Statistical Summary of the Constructs: Means, Standard Deviations and Correlations $(N=278)$

These findings are consistent with the theoretical proposals of Augier and Teece (2009), who argue that service providers need high levels of skills, abilities and experiences to build dynamic capabilities in order to adopt to rapidly changing environment. The results confirmed and reveals that dynamic capabilities have a direct positive effect on value based education outcomes. In other words, the data show that dynamic capabilities act as mediators between existing environment (having the usual technological development) and unexpected conditions (digitalisation caused by COVID-19) and the learning outcomes.

\section{Conclusions}

In general, the education system is not an environment of particularly significant and unanticipated transition. Educational ecosystem is facing rapid changes mainly due emerging technologies and their rapid penetration to daily use. When the COVID-19 pandemic emerged, it only accelerated many of these trends. Nevertheless, some education systems have been able to adapt to the changing situation and digital transformation more easily than others. The usual diffusion of technology and innovation is due to the inevitable development of the educational ecosystem and the shift in service delivery and communication networks. Under normal conditions, educators can choose the usual means for their activities and the way services are provided. After the COVID-19 lockdown was implemented in a very short period of time, there was a need to solve problems related to the education system. The lowest losses were for those institutions that had previously started the process of implementing digital change before the COVID-19 pandemic. In addition, those who took the initiative faster, reoriented and changed their operating strategies without waiting for management instructions and understood how to properly address the problem and invest in the 
Trinkūnienè \& Juškaite, 2021. Covid-19 and the Digital Transformation of Education: the Case of Latvia and Lithuania

digitization of the institution, won less stress, lost revenue, did not lose jobs. In addition, they were able to ensure timely uninterrupted service and quality of service. E-learning and distance learning became the main and only one possible way to ensure the educational services. In addition, it was very important to ensure the quality of services. The results of the study showed that dynamic capabilities play an important role in adapting to the changed and volatile climate that has evolved in the context of COVID-19 in order to ensure added value for educational outcomes across various educational service delivery channels (elearning, distance learning, etc.). The results of the survey revealed that $57.59 \%$ of respondents are in favour of the transition to e-learning. $64.02 \%$ of respondents to the survey say that the results of training services have not changed or even improved. As many as $82.7 \%$ of the respondents indicated the possibility to feel, use and reconfigure the current situation as the main element of change. Nevertheless, the results revealed the unexpected result that $36,84 \%$ of learners (regardless of their young age) do not have the right digital skills and sufficient digital literacy.

\section{Acknowledgements}

Researchers would like to thank for RTU preparation course department, Asta Karaliūtė-Bredelienè (Vilnius Lyceum), Jolita Norkunaite (The American International School of Vilnius), Riga Lithuanian Secondary School for assistance with data collection.

\section{References}

Abdelaal, M. H. I., Khater, M., \& Zaki, M. (2018). Digital business transformation and strategy: What do we know so far? University of Cambridge.

Amit, R., \& Schoemaker, P. J. (1993). Strategic assets and organizational rent. Strategic management journal, 14(1), 33-46.

Arndt, F., \& Pierce, L. (2018). The behavioral and evolutionary roots of dynamic capabilities. Industrial and corporate change, 27(2), 413-424.

Augier, M., \& Teece, D. J. (2009). Dynamic capabilities and the role of managers in business strategy and economic performance. Organization science, 20(2), 410-421.

Daugule, I., \& Kapenieks, A. (2019). Knowledge flow analysis: the quantitative method for knowledge stickiness analysis in online course. Periodicals of Engineering and Natural Sciences, 7(1), 165-171.

ec.europa.eu. (2020). Retrieved from https://ec.europa.eu/eurostat/web/europe-2020-indicators

Entwistle, N. (1988). Motivation and learning strategies. Educational and Child Psychology, 5(3), 5-20.

Entwistle, N., Hanley, M., \& Hounsell, D. (1979). Identifying distinctive approaches to studying. Higher education, 8(4), 365-380.

Entwistle, N. J., \& Ramsden, P. (1983). Understanding student learning. London: Croom Helm. 
Entwistle, N., \& Tait, H. (1990). Approaches to learning, evaluations of teaching, and preferences for contrasting academic environments. Higher Education, 19(2), 169194.

EU. (2019). "10 trends transforming education as we know it". Retrieved from https://op.europa.eu/lv/publication-detail/-/publication/227c6186-10d0-11ea-8c1f01aa75ed71a1/language-en

Henry, P. (2001). E-learning technology, content and services. Education+ Training.

Katz, L. F., \& Goldin, C. D. (2008). The race between education and technology. Cambridge: Harvard university press.

Lee, M. K., Cheung, C. M., \& Chen, Z. (2005). Acceptance of Internet-based learning medium: the role of extrinsic and intrinsic motivation. Information \& management, 42(8), 1095

Loonam, J., Eaves, S., Kumar, V., \& Parry, G. (2018). Towards digital transformation: Lessons learned from traditional organizations. Strategic Change, 27(2), 101-109.

Mason, G., Holland, D., Liadze, I., O'Mahony, M., Riley, R., \& Rincon-Aznar, A. (2014). Macroeconomic benefits of vocational education and training. Cedefop Research Paper, 40.

Matt, C., Hess, T., \& Benlian, A. (2015). Digital transformation strategies. Business \& Information Systems Engineering, 57(5), 339-343.

NEF. (2017). Retrieved from https://neweconomics.org/2017/09/nef-news-september-2017

OECD. (2020). Webinar 29.10.2020. Digitalisation today: benefits and risks for higher education. Retrieved from https://oecdedutoday.com/oecd-education-webinars/

OECD. (2019). Trends shaping education. Retrieved from http://www.oecd.org/ education/trends-shaping-education-22187049.htm

Petrulytè, A. (1995). Kūrybiškumo ugdymo aktualijos. Vilnius: Leidybos centras.

Ramsden, P., \& Entwistle, N. J. (1981). EFFECTS OF ACADEMIC DEPARTMENTS ON STUDENTS'APPROACHES TO STUDYING. British journal of educational psychology, 51(3), 368-383.

Salvato, C., \& Vassolo, R. (2018). The sources of dynamism in dynamic capabilities. Strategic Management Journal, 39(6), 1728-1752.

Schoemaker, P. J., Heaton, S., \& Teece, D. (2018). Innovation, dynamic capabilities, and leadership. California Management Review, 61(1), 15-42.

Sebastian, I., Ross, J., Beath, C., Mocker, M., Moloney, K., \& Fonstad, N. (2017). How big old companies navigate digital transformation.

Sphoher J. (n.d.). Slideshare. Retrieved from www.slideshare.net/spohrer/t-shaped-people20130628-v5

Teece, D. J. (2007). Explicating dynamic capabilities: the nature and microfoundations of (sustainable) enterprise performance. Strategic management journal, 28(13), 1319-1350.

Teece, D. J., Pisano, G., \& Shuen, A. (1997). Dynamic capabilities and strategic management. Strategic management journal, 18(7), 509-533.

UNESCO. (I2017). UNESCO Education. Retrieved from www.unesco.org/new/ en/education/themes/strengthening-education-systems/quality-framework/desiredoutcomes/competencies 